\title{
Urotensin II enhances transforming growth factor- $\beta 1$ expression and secretion in the kidney during aristolochic acid nephropathy
}

\author{
SUXIAN CHEN $^{1}$, YADI WANG ${ }^{2}$ and YIZENG WAN ${ }^{1}$ \\ Departments of ${ }^{1}$ Pathology and ${ }^{2}$ Oncology, The Third Hospital Affiliated to The \\ Liaoning Medical University, Jinzhou, Liaoning 121001, P.R. China
}

Received September 5, 2016; Accepted May 12, 2017

DOI: $10.3892 / \mathrm{mmr} .2017 .7424$

\begin{abstract}
Aristolochic acid is a component of many types of Chinese medicine, which are commonly used to treat almost all human diseases. However, aristolochic acid may cause nephropathy. Urotensin II (UII) and transforming growth factor (TGF)- $\beta 1$ are important signaling factors, which are expressed at elevated levels during the development of nephropathy. However, the association between UII and TGF- $\beta 1$ expression remains unclear. In the current study, the regulatory association between UII and TGF- $\beta 1$ expression was investigated using a rat aristolochic acid nephropathy model and the NRK-52E cell line. The expression levels of UII and TGF- $\beta 1$ were identified to be constantly increased in the rat aristolochic acid nephropathy model, even 10 days after administration of Aristolochiae manshuriensis decoction was terminated. Notably, increases in the TGF- $\beta 1$ expression levels occurred later than those of UII. Furthermore, UII enhanced TGF- $\beta 1$ expression in, and secretion from, NRK-52E cells. These data indicate that UII and TGF- $\beta 1$ are important in the development of aristolochic acid nephropathy, and UII enhances TGF- $\beta 1$ expression levels and secretion during aristolochic acid nephropathy. However, the underlying mechanisms for the precise roles of UII and TGF- $\beta 1$ as well as the method by which UII regulates the expression TGF- $\beta 1$ in aristolochic acid nephropathy remain to be elucidated in future studies.
\end{abstract}

\section{Introduction}

Aristolochic acid is a component of numerous types of Chinese medicines that are commonly used to treat almost all diseases of systems in the human body, from the skin to the internal organs $(1,2)$. However, aristolochic acid is detrimental

Correspondence to: Dr Yizeng Wan, Department of Pathology, The Third Hospital Affiliated to The Liaoning Medical University, 2-5 Heping Road, Jinzhou, Liaoning 121001, P.R. China

E-mail: 13504060890@163.com

Key words: aristolochic acid nephropathy, rat model, NRK-52E cells, urotensin II, transforming growth factor- $\beta 1$ to the kidneys $(3,4)$. The renal damage resulting from aristolochic acid is irreversible and progresses long after the use of the drugs has stopped. Aristolochic acid nephropathy is the primary cause of renal failure in the elderly in China, where people often take traditional medicine that contain aristolochic acid (5); however, the underlying mechanism remains unclear.

Urotensin II (UII) is abundant and the most potent vasoconstrictive peptide in the kidneys (6). As a neuronal regulatory peptide $(7,8)$, UII regulates the dynamics of blood flow, and increases extracellular matrix production and regulates matrix metalloproteinase-2 activity (9-11). Studies have demonstrated that UII promotes the proliferation of renal tubular epithelial cells (12), activates the epidermal growth factor receptor in rat renal tubular epithelial cells via the SHP-2 signaling pathway (13), inhibits renal tubular reabsorption of potassium and sodium (14), promotes intracellular calcium release (15) and inhibits apoptosis in NRK-52E rat proximal tubular epithelial cells (16). In addition, UII has been proposed as a target for treating patients with hypervolemic cardio-renal syndrome (17). UII exerts a potent vasoconstrictive action as well as renal profibrotic effects (18). Aristolochic acid increases the expression level of UII and its receptor urotensin 2 receptor (UTS2R) in renal tubular epithelial cells in a dose-dependent manner (19). Therefore, UII is an important factor in the development of renal disease.

Transforming growth factor (TGF)- $\beta 1$ is a pleiotropic protein, involved in cell growth, differentiation, immune regulation, inflammation and injury repair. TGF- $\beta 1$ is expressed in the proximal tubule and collecting duct $(20,21)$, and induces the differentiation of renal tubular epithelial cells (22). As a pleiotropic cytokine, TGF- $\beta 1$ aggravates fibrotic renal lesions by promoting the accumulation of the extracellular matrix, and is a required component in tissue repair based on coordinated actions with other cytokines (23-25).

In a model of acute ischemic renal injury, the expression and activity of TGF- $\beta 1$ are significantly increased in papillary hyperplasia in the proximal renal tubule (26). The TGF- $\beta 1$ receptor is expressed in the newly formed renal tubules in the outer medulla, which indicates that TGF- $\beta 1$ is important in the regeneration of renal tubules (27). Following renal epithelial cell repair, the persistent increase in TGF- $\beta 1$ expression may result in activation of renal interstitial fibroblasts and macrophages, collagen deposition and renal fibrosis (28). Therefore, 
TGF- $\beta 1$ is considered to be a critical signaling factor in nephropathy.

Studies have indicated that treatment of animals with high doses of UII leads to increased expression levels of TGF- $\beta 1$ in hepatocytes (29), and TGF- $\beta 1$ is involved in the UII-induced phenotypic differentiation of rat aortic fibroblasts (30). Furthermore, upregulation of UII and its receptor, UTS2R is important in TGF- $\beta 1$-mediated renal fibrosis and dysfunction in diabetes (18). The above-mentioned studies suggest that there is an interplay between TGF- $\beta 1$ and UII. As TGF- $\beta 1$ and UII are important factors in nephropathy, the current study investigated the regulatory association between the two in aristolochic acid nephropathy using a rat aristolochic acid nephropathy model and the NRK-52E cell line.

\section{Materials and methods}

Reagents. Chinese herbal medicine Guanmutong (Aristolochiae Manshuriensis) was purchased from the Jilin Hongjian Medical Company (Changchun, China). The NRK-52E cells were a gift from the Laboratory of Pharmacology and Toxicology at the Medicine College of Jilin University (Changchun, China). Aristolochic sodium was purchased from the National Institute for Food and Drug Control (Beijing, China). Gibco Dulbecco's modified Eagle's medium (DMEM) was purchased from Thermo Fisher Scientific, Inc. (Waltham, MA, USA). TRIzol reagent, AMV reverse transcriptase, and Taq DNA polymerase were purchased from Invitrogen (Thermo Fisher Scientific, Inc.). UII (catalog no. U7257) and anti-UII antibody (catalog no. sc52300) were purchased from Sigma-Aldrich (Merck KGaA, Darmstadt, Germany). TGF- $\beta 1$ and the primary (catalog no. BA0290) and secondary TGF- $\beta 1$ antibody (catalog no. BA1504) were purchased from Wuhan Boster Biological Technology, Ltd. (Wuhan, China).

A. manshuriensis decoction (AMD) was prepared using $1 \mathrm{~kg}$ crude A. manshuriensis drug. The crude drug was soaked in 2 liters of water for $30 \mathrm{~min}$ and boiled for $1 \mathrm{~h}$. The liquid was collected and water was added to the crude drug residue, the solution was then boiled for another $1 \mathrm{~h}$. The liquid was collected, combined with the first liquid and cleaned by filtration. Finally, after the drug was concentrated $(2 \mathrm{~g}$ crude drug $/ \mathrm{ml}$ ), a 500-ml decoction was obtained and stored at $4^{\circ} \mathrm{C}$. The decoction was pre-warmed at $4^{\circ} \mathrm{C}$ immediately before administration by gavage.

Rat aristolochic acid nephropathy model. Sixty male Wistar rats (weight, 180-220 g) were housed in the Center for Experimental Animals in Liaoning Medical University (Jinzhou, China) were randomly divided into two groups as follows: The control group $(n=10)$, which received normal saline $(10 \mathrm{ml} / \mathrm{kg})$ once a day; and the aristolochic acid nephropathy model (AMK) group $(n=50)$, which received AMD $(20 \mathrm{~g} / \mathrm{kg})$ once a day for up to 25 days. Ten rats in the AMK group were sacrificed by cervical dislocation at each of the following time points: 3, 7, 15 and 25 days of treatment. The last 10 AMK rats were sacrificed by cervical dislocation 10 days after the 25-day treatment with AMD, together with the rats in the control group. AMD or the normal saline was administered by gavage. Kidneys were collected for hematoxylin and eosin (H\&E) staining, and determination of UII and TGF- $\beta 1$ gene expression levels. The protocols for the use of animals in the current study were approved by the Ethics Committee for Animal Experimentation of Liaoning Medical University.

Histopathological examination of kidneys of aristolochic acid nephropathy model rats. The kidney tissue samples were fixed in $10 \%$ formalin solution for $48 \mathrm{~h}$ and placed in embedding boxes. Following serial dehydration in $80-95 \%$ ethanol for $3 \mathrm{~h}$ (twice) and 100\% ethanol for $3 \mathrm{~h}$ (three times) and treatment with xylene for $2 \mathrm{~h}$, the tissue samples were embedded in paraffin. The paraffin blocks containing the kidney tissue samples were sectioned into $3-\mu \mathrm{m}$ slices, which were then hydrated at $52^{\circ} \mathrm{C}$ and fixed on slides at $60^{\circ} \mathrm{C}$ in an oven for $30 \mathrm{~min}$. The slices were then stained with H\&E following standard protocol. Finally, the slices were sealed with neutral resin and coverslips. The specimens were examined using a light microscope (BX-51; Olympus Corporation, Tokyo, Japan).

Cell culture and treatment. NRK-52E cells were maintained in DMEM supplemented with $10 \%$ fetal bovine serum (FBS; Tian Jin Hao Yang Biological Manufacture Co., Ltd., Tianjin, China) in a cell incubator at $37^{\circ} \mathrm{C}$ with an atmosphere of $5 \%$ $\mathrm{CO}_{2}$. For treatment, NRK-52E cells were detached from the plates using $0.25 \%$ trypsin, suspended and seeded in 12-well plates at a density of $1 \times 10^{4} /$ well. The cells were combined with serum-free media. Following incubation at $37^{\circ} \mathrm{C}$ for $24 \mathrm{~h}$, the cells were maintained at $37^{\circ} \mathrm{C}$ with medium containing $0.5 \%$ FBS. Cells were treated with DMEM, UII $\left(10^{-8} \mathrm{~mol} / \mathrm{l}\right)$, or UII + anti-UII antibody $\left(10^{-5} \mathrm{~mol} / \mathrm{l}\right)$. DMEM served as the vehicle. Each treatment group included 6 wells, and cells and media were collected for testing after $48 \mathrm{~h}$.

Determination of UII and TGF- $\beta 1$ mRNA expression levels using reverse transcription-quantitative polymerase chain reaction $(R T-q P C R)$. Total RNA was extracted from kidney tissues or NRK-52E cells using Invitrogen TRIzol reagent according to the manufacturer's protocol (Thermo Fisher Scientific, Inc.). cDNA was synthesized using Invitrogen AMV reverse transcriptase (Thermo Fisher Scientific, Inc.). PCR was performed using Taq DNA polymerase (Nanjing KeyGen Biotech Co., Ltd., Nanjing, China) on a Cleaver Scientific thermocycler (model PCT25; Beijing Dingguo Changsheng Biotechnology Co., Ltd., Beijing, China) with the following cycling program: $94^{\circ} \mathrm{C}$ for $5 \mathrm{~min} ; 30$ cycles of $94^{\circ} \mathrm{C}$ for $45 \mathrm{sec}, 53^{\circ} \mathrm{C}$ for $\mathrm{UII} / 59^{\circ} \mathrm{C}$ for $\mathrm{TGF}-\beta 1 / 55^{\circ} \mathrm{C}$ for $\mathrm{GAPDH}$ for $45^{\circ} \mathrm{sec}, 72^{\circ} \mathrm{C}$ for $45 \mathrm{sec}$; and a final extension at $72^{\circ} \mathrm{C}$ for $10 \mathrm{~min}$. The PCR products were examined using agarose gel electrophoresis, using a $2 \%$ agarose gel at $3 \mathrm{~V}$ for $30-50 \mathrm{~min}$. The bands were recorded, and their densities were quantified using a Tanon GIS-1000 gel image processing system (Tocan Co., Ltd., Shanghai, China). GAPDH served as a reference gene to determine the relative expression levels of UII and TGF- $\beta 1$ by calculating the ratio of UII or TGF- $\beta 1 /$ GAPDH densities. The primers were synthesized by Sangon Biotech Co., Ltd. (Shanghai, China). The amplicon for UII was $242 \mathrm{bp}$ in length and the primers were as follows: Sense, 5'-TGC CTG CTC TTC GTA GGA CT-3' and antisense, 5'-AGA GCC TTC CTC AAG CTT CC-3'. The amplicon for TGF- $\beta 1$ was $382 \mathrm{bp}$ in length and the primers were as follows: 


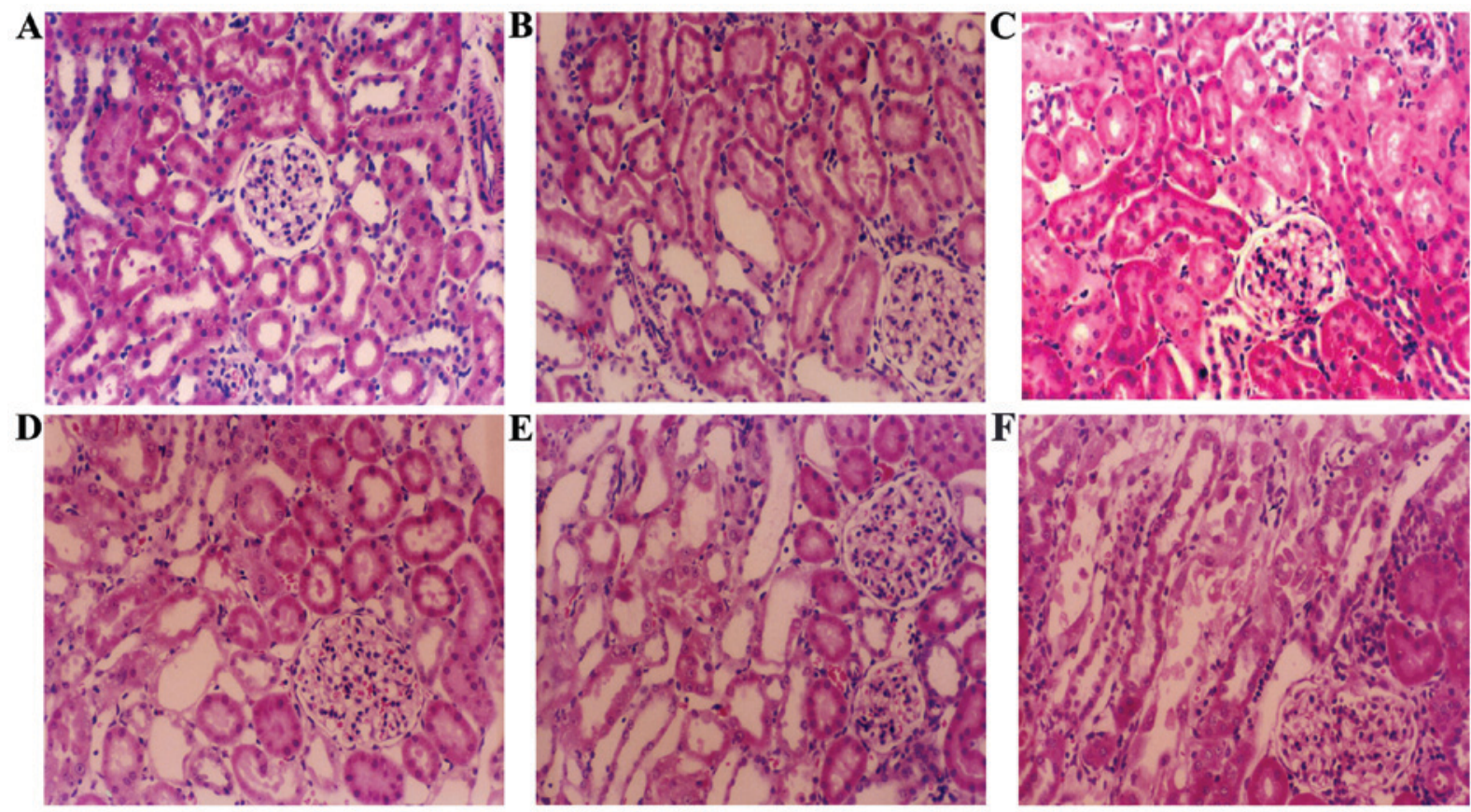

Figure 1. Histopathology of the tubules and glomerulus of kidneys from the AMK rats. Rats were treated with Aristolochiae manshuriensis decoction (20 g/kg) once a day for up to 25 days, and sacrificed after 3, 7, 15, 25 and 35 days of treatment. Kidney tissue samples were collected, fixed, and stained using hematoxin and eosin. (A) Control group, and AMK groups sacrificed after (B) 3, (C) 7, (D) 15, (E) 25 and (F) 35 days. Magnification, x200. AMK, aristolochic acid nephropathy model.

Sense, 5'-GAC CTC AAT TGC GAG CTT TC-3' and antisense, 5'-AGT CCT CCT TCC GCC TTT AG-3'. The amplicon for GAPDH was $450 \mathrm{bp}$ in length and the primers were as follows: Sense, 5'-ACC ACA GTC CAT GCC ATC AC-3' and antisense, 5'-TCC ACC ACC CTG TTG CTG TA-3'.

Determination of TGF- $\beta 1$ concentrations by enzyme-linked immunosorbent assay (ELISA). After NRK-52E cells were treated with DMEM, UII, or UII + anti-UII antibody for $48 \mathrm{~h}$, the medium was collected using centrifugation at $800 \mathrm{x} \mathrm{g}$ for $5 \mathrm{~min}$. Each medium sample $(10 \mu \mathrm{l})$ was aliquoted in 96 -well plates, mixed with $90 \mu 1$ of $0.06 \mathrm{~mol} / \mathrm{l}$ carbonate buffer (pH 9.6) and stored at $4^{\circ} \mathrm{C}$ overnight. After removal of the supernatant, $200 \mu 1$ blocking buffer (PBS containing 2\% FBS) was added to each well of the plate and incubated at $37^{\circ} \mathrm{C}$ for $1.5 \mathrm{~h}$. The samples were then washed three times with PBS containing Tween-20 (PBST) for $3 \mathrm{~min}$. Next, $100 \mu \mathrm{l}$ primary antibody to TGF- $\beta 1(1: 1,000)$ was added to the wells and incubated at $37^{\circ} \mathrm{C}$ for $2 \mathrm{~h}$. After three washes with PBST for $3 \mathrm{~min}$ each, $100 \mu \mathrm{l}$ secondary antibody (catalog no. BA1504; 1:2,000) was added and incubated at $37^{\circ} \mathrm{C}$ for $1.5 \mathrm{~h}$. After three washes with PBST for $3 \mathrm{~min}$ each, $100 \mu \mathrm{l}$ diaminobenzidine (DAB) solution [6 mg DAB dissolved in $10 \mathrm{ml}$ of $0.01 \mathrm{~mol} / 1$ Tris- $\mathrm{Cl}(\mathrm{pH} 7.6)$ and $10 \mu \mathrm{H}_{2} \mathrm{O}_{2}$ ] was added to the wells and incubated in the dark for 3-5 min. Finally, $50 \mu \mathrm{l}$ stop solution $\left(2 \mathrm{~mol} / 1 \mathrm{H}_{2} \mathrm{SO}_{4}\right)$ was added. The optical absorbance was read at a wavelength of $490 \mathrm{~nm}$ using a Microplate Reader (Multiskan Spectrum; Thermo Fisher Scientific, Inc.).

Statistical analysis. Data were analyzed using SPSS 13.0 (SPSS, Inc., Chicago, IL, USA). Statistical differences were analyzed using Student's t-tests and $\mathrm{P}<0.05$ was considered to indicate a statistically significant difference.

\section{Results}

Establishment of the rat aristolochic acid nephropathy model. To investigate the mechanism underlying aristolochic acid nephropathy, a rat aristolochic acid nephropathy model was established using AMD. The result demonstrated that there were no morphological changes in the tubules and glomerulus in the kidney of rats in the control group, whereas treatment of rats with AMD for 3 days resulted in degeneration, necrosis, and disintegration of epithelial cells in the proximal tubules. Only a small quantity of inflammatory cell infiltration and no morphology changes were observed in the glomerulus.

Treatment of rats with AMD for 7 and 15 days resulted in increased necrosis among proximal tubular epithelial cells. Treatment of rats with AMD for 25 days resulted in mass necrosis, disintegration, and detachment of the proximal tubular epithelial cells and increased fibrous tissue in the lesion; however, there was less infiltration of inflammatory cells compared with the model group. Protein casts were visible in distal tubular lumens and there were no significant morphological changes in the glomerulus (Fig. 1). Ten days after treatment with AMD for 25 days, no significant differences were observed in the kidney when compared with that immediately after 25 days of treatment (Fig. 1). These results indicate that the rat aristolochic acid nephropathy model had successfully been established.

Renal UII and TGF- $\beta 1$ mRNA expression levels. The renal UII and TGF- $\beta 1$ mRNA expression levels in the AMK models and the controls were examined in the present study. The results demonstrated that UII mRNA expression levels were constantly increased in rats treated with AMD for 7, 15 and 25 days, compared with the control group, and the UII mRNA 
Table I. Relative UII and TGF- $\beta 1 \mathrm{mRNA}$ expression levels in the kidneys.

\begin{tabular}{lcc}
\hline Group & UII & TGF- $\beta 1$ \\
\hline Control & $0.62 \pm 0.07$ & $0.35 \pm 0.06$ \\
Aristolochic acid & & \\
nephropathy model & & \\
3 days & $0.68 \pm 0.08$ & $0.37 \pm 0.06$ \\
7 days & $0.78 \pm 0.06^{\mathrm{a}}$ & $0.42 \pm 0.08$ \\
15 days & $0.86 \pm 0.06^{\mathrm{b}}$ & $0.50 \pm 0.02^{\mathrm{a}}$ \\
25 days & $0.90 \pm 0.08^{\mathrm{b}}$ & $0.56 \pm 0.05^{\mathrm{b}}$ \\
35 days & $0.97 \pm 0.08^{\mathrm{b}}$ & $0.68 \pm 0.09^{\mathrm{b}}$ \\
\hline
\end{tabular}

${ }^{\mathrm{a}} \mathrm{P}<0.05$ and ${ }^{\mathrm{b}} \mathrm{P}<0.01$ vs. the control group. UII, urotensin II; TGF- $\beta 1$, transforming growth factor- $\beta 1$. Data are presented as the mean \pm standard deviation.

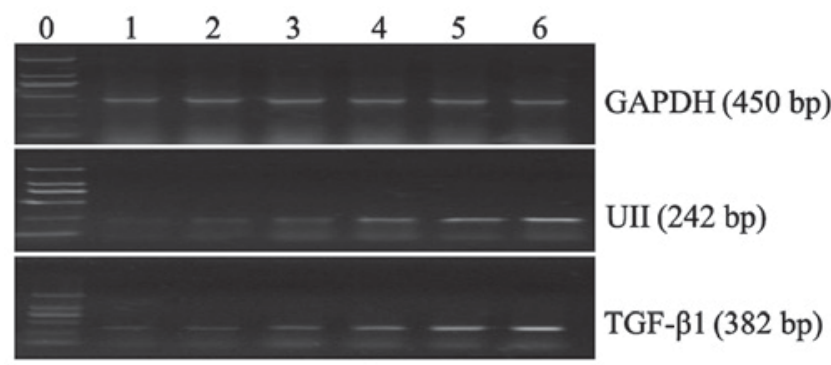

Figure 2. Relative levels of UII and TGF- $\beta 1$ mRNA expression in kidneys from AMK rats. Rats were treated with Aristolochiae manshuriensis decoction $(20 \mathrm{~g} / \mathrm{kg})$ once a day for up to 25 days, and sacrificed after $3,7,15,25$ and 35 days. Total RNA samples were extracted from kidney tissue samples. Relative mRNA levels were determined using reverse transcription-quantitative PCR. The PCR products were examined using agarose gel electrophoresis. Lane 0, molecular marker; lane 1, control; lane 2, 3 days; lane 3, 7 days; lane 4, 15 days; lane 5, 25 days; and lane 6, 35 days. UII, urotensin II; TGF- $\beta 1$, transforming growth factor- $\beta 1$; PCR, polymerase chain reaction; AMK, aristolochic acid nephropathy model.

expression levels were not decreased even 10 days after treatment with AMD was terminated (Table I and Fig. 2). Similarly, TGF- $\beta 1$ mRNA expression levels were constantly increased in the rats treated with AMD for 15 and 25 days, and these levels were not decreased even after treatment with AMD was terminated (Table I and Fig. 2).

UII enhanced TGF- $\beta 1$ expression in NRK-52E cells. To examine the effect of UII on TGF- $\beta 1$ expression levels, the intracellular TGF- $\beta 1$ mRNA expression levels and the secretion of TGF- $\beta 1$ into the culture medium of NRK-52E cells treated with UII, UII + anti-UII and the vehicle control. The results indicated that the TGF- $\beta 1$ mRNA expression levels were greater in NRK-52E cells treated with UII than in the control group ( $0.76 \pm 0.06$ vs. $0.39 \pm 0.08 ; \mathrm{P}<0.05$; Fig. 3$)$. Neutralization of UII using the specific antibody significantly decreased the TGF- $\beta 1$ mRNA expression levels in NRK-52E cells treated with UII, compared with those in the UII group $(0.58 \pm 0.03$ vs. $0.76 \pm 0.06 ; \mathrm{P}<0.05$; Fig. 3 ). These results indicate that UII enhanced TGF- $\beta 1$ expression levels in NRK-52E cells.

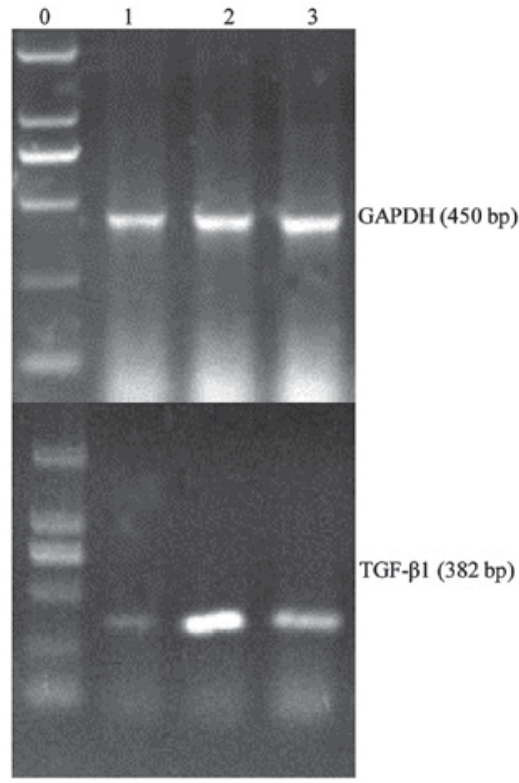

Figure 3. Relative expression levels of TGF- $\beta 1 \mathrm{mRNA}$ in NRK-52E cells Cells were treated with DMEM, UII, or UII + anti-UII for $48 \mathrm{~h}$. Total RNA samples were extracted from cells. Relative mRNA levels were determined using reverse transcription-PCR. The PCR products were examined using agarose gel electrophoresis. Lane 0, molecular marker; lane 1, DMEM; lane 2, UII; lane 3, UII + anti-UII antibody. TGF- $\beta 1$, transforming growth factor- $\beta 1$; DMEM, Dulbecco's modified Eagle's medium; UII, urotensin II; $\mathrm{PCR}$, polymerase chain reaction.

TGF- $\beta 1$ protein expression levels were significantly greater in the medium of NRK-52E cells treated with UII $(0.32 \pm 0.03)$ and UII + anti-UII $(0.19 \pm 0.01)$ compared with the expression levels in the control group $(0.16 \pm 0.03 ; \mathrm{P}<0.05)$. Neutralization of UII using the specific antibody significantly decreased the TGF- $\beta 1$ protein expression levels in the medium of NRK-52E cells treated with UII, compared with those in the UII group (Fig. 3). These results indicated that UII enhanced the secretion of TGF- $\beta 1$ by NRK-52E cells.

\section{Discussion}

Aristolochic acid nephropathy is a common occurrence; however, the underlying molecular mechanism remains unknown. TGF- $\beta 1$ and UII are important factors in nephropathy, and the regulatory association between the two remains unknown. In the current study, a rat aristolochic acid nephropathy model was successfully established using AMD to investigate the mechanism underlying this type of fibrosis. The expression of UII and TGF- $\beta 1$ was identified to be constantly increased in the rat aristolochic acid nephropathy model, even 10 days after the use of AMD was terminated. These data indicate that UII and TGF- $\beta 1$ may be important in the development of aristolochic acid nephropathy.

Notably, increases in TGF- $\beta 1$ expression levels occurred later than those of UII in the aristolochic acid nephropathy model rats. Furthermore, UII enhanced TGF- $\beta 1$ expression levels in and secretion from NRK-52E cells. These data indicate that UII enhances TGF- $\beta 1$ expression and secretion during aristolochic acid nephropathy. Furthermore, the current finding is consistent with that of a previous study (19) showing that TGF- $\beta 1$ is involved in the UII-induced phenotypic 
differentiation of rat aortic fibroblasts (30). Treatment of rats with high doses of UII leads to increased expression of TGF- $\beta 1$ in hepatocytes (29). Thus, it is likely that UII is a positive regulator of TGF- $\beta 1$ expression. However, the method by which the expression of UII and TGF- $\beta 1$ is increased and how UII regulates the expression of TGF- $\beta 1$ during aristolochic acid nephropathy requires further investigation.

The interplay between the expression levels of UII and TGF- $\beta 1$ may lead to functional interactions between UII and TGF- $\beta 1$. Fibrosis is characterized by hyperactivity of TGF- $\beta 1$, which results in disruption of extracellular matrix homeostasis and accumulation of fibrosis-associated proteins (31). Elevated TGF- $\beta 1$ expression levels causatively activate profibrotic signaling pathways in ureteral obstruction-induced renal fibrosis (32). It has been demonstrated that UII promotes collagen synthesis via ERK1/2-dependent and -independent TGF- $\beta 1$ signaling pathways in neonatal cardiac fibroblasts (33). UII expression levels were increased in diabetic renal fibrosis and functional disorders likely via autocrine or paracrine secretion mechanisms, and thus, UII is important in TGF- $\beta 1$-regulated renal fibrosis and dysfunction (18). Furthermore, UII was identified as an important mediator in an experimental lung fibrosis rat model (34). Increased levels of UII modulate hepatic fibrosis and portal hemodynamic alterations in rats (29), and UII is involved in the development of cardiac fibrosis and hypertrophy $(35,36)$. Thus, renal fibrotic changes during aristolochic acid nephropathy appear to be associated with an interaction between UII and TGF- $\beta 1$.

In conclusion, UII and TGF- $\beta 1$ expression levels were observed to be increased, and UII enhanced TGF- $\beta 1$ expression and secretion during aristolochic acid nephropathy. These findings contribute to the hypothesis of the interplay between UII and TGF- $\beta 1$ in the development of and recovery from aristolochic acid nephropathy. However, the underlying mechanism of the precise role of UII and TGF- $\beta 1$ in aristolochic acid nephropathy, and the way in which UII regulates TGF- $\beta 1$ expression, remains to be fully elucidated in future studies.

\section{References}

1. Jong TT, Lee MR, Hsiao SS, Hsai JL, Wu TS, Chiang ST and Cai SQ: Analysis of aristolochic acid in nine sources of Xixin, a traditional Chinese medicine, by liquid chromatography/atmospheric pressure chemical ionization/tandem mass spectrometry. J Pharm Biomed Anal 33: 831-837, 2003.

2. Wang HT, Wang YM, Liang YP, Liu YJ and Peng W: Wenyang Huoxue Recipe up-regulates the expression of angiopoietin-1 mRNA in rats with chronic aristolochic acid nephropathy. Zhong Xi Yi Jie He Xue Bao 6: 508-511, 2008 (In Chinese).

3. Grollman AP: Aristolochic acid nephropathy: Harbinger of a global iatrogenic disease. Environ Mol Mutagen 54: 1-7, 2013.

4. Nortier JL, Schmeiser HH, Muniz Martinez MC, Arlt VM, Vervaet C, Garbar CH, Daelemans P and Vanherweghem JL: Invasive urothelial carcinoma after exposure to Chinese herbal medicine containing aristolochic acid may occur without severe renal failure. Nephrol Dial Transplant 18: 426-428, 2003.

5. Vanherweghem JL, Depierreux M, Tielemans C, Abramdwicz D, Dratwa M, Jadoul M, Richard C, Vandervelde D, Verbeelen D, Vanhaelen-Fastre R, et al: Rapidly progressive interstitial renal fibrosis in young women: Association with slimming regimen including Chinese herds. Lancet 341: 387-391, 1993.

6. Vaudry H, Leprince J, Chatenet D, Fournier A, Lambert DG, Le Mével JC, Ohlstein EH, Schwertani A, Tostivint H and Vaudry D: International union of basic and clinical pharmacology. XCII. Urotensin II, urotensin II-related peptide, and their receptor: From structure to function. Pharmacol Rev 67: 214-258, 2015.
7. Egginger JG, Camus A and Calas A: Urotensin-II expression in the mouse spinal cord. J Chem Neuroanat 31: 146-154, 2006.

8. Jegou S, Cartier D, Dubessy C, Gonzalez BJ, Chatenet D, Tostivint H, Scalbert E, LePrince J, Vaudry H and Lihrmann I: Localization of the urotensin II receptor in the rat central nervous system. J Comp Neurol 495: 21-36, 2006.

9. Diebold I, Petry A, Burger M, Hess J and Görlach A: NOX4 mediates activation of FoxO3a and matrix metalloproteinase-2 expression by urotensin-II. Mol Biol Cell 22: 4424-4434, 2011.

10. Lu W, Abdel-Razik AE, Ashton N and Balment RJ: Urotensin II: Lessons from comparative studies for general endocrinology. Gen Comp Endocrinol 157: 14-20, 2008.

11. Richards AM and Charles C: Urotensin II in the cardiovascular system. Peptides 25: 1795-1802, 2004.

12. Chen SX, Li C, Miao CS, Zhang XY and Fan Z: Mitogenic effect of urotensin II on the renal tubular epithelial cells in rats. J Jilin Univ (Med Ed) 33: 204-206, 2007 (In Chinese).

13. Sue YM, Chen CH, Hsu YH, Hou CC, Cheng CY, Chen YC, Lin SL, Chen TW and Chen TH: Urotensin II induces transactivation of the epidermal growth factor receptor via transient oxidation of SHP-2 in the rat renal tubular cell line NRK-52E. Growth Factors 27: 155-162, 2009.

14. Abdel-Razik AE, Forty EJ, Balment RJ and Ashton N: Renal haemodynamic and tubular actions of urotensin II in the rat. J Endocrinol 198: 617-624, 2008.

15. Adebiyi A: RGS2 regulates urotensin II-induced intracellular $\mathrm{Ca} 2+$ elevation and contraction in glomerular mesangial cells. J Cell Physiol 229: 502-511, 2014.

16. Hsu YH, Chen TH, Chen YC, Cheng CY, Sue YM, Chen JR and $\mathrm{Chen} \mathrm{CH}$ : Urotensin II exerts antiapoptotic effect on NRK-52E cells through prostacyclin-mediated peroxisome proliferator-activated receptor alpha and Akt activation. Mol Cell Endocrinol 381: 168-174, 2013

17. Yilmaz B, Yilmaz A, Sari F, Sarikaya AM, Ellidag HY, Kucukseymen S and Ozpelit E: Decrease of Urotensin II activity can impact on the volume status in predialysis chronic kidney disease. Ren Fail 37: 476-481, 2015.

18. Tian L, Li C, Qi J, Fu P, Yu X, Li X and Cai L: Diabetes-induced upregulation of urotensin II and its receptor plays an important role in TGF-beta1-mediated renal fibrosis and dysfunction. Am J Physiol Endocrinol Metab 295: E1234-E1242, 2008.

19. Chen S and Wan Y: The effect of Aristolochic acid on UII and GPR14 mRNA levels in the renal tubular epithelial cells. Shandong Pharm 52: 36-38, 2012 (In Chinese).

20. Ruiz-Torres MP, Bosch RJ, O'Valle F, Del Moral RG, Ramírez C, Masseroli M,Pérez-Caballero C, Iglesias MC, Rodríguez-Puyol M and Rodríguez-Puyol D: Age-related increase in expression of TGF-betal in the rat kidney: Relationship to morphologic changes. J Am Soc Nephrol 9: 782-791, 1998

21. Lúdvíksson BR, Seegers D, Resnick AS and Strober W: The effect of TGF-betal on immune responses of naive versus memory CD4+ Th1/Th2 T cells. Eur J Immunol 30: 2101-2111, 2000.

22. Zeng H, Zhou Y and Yao GY: Transforming growth factor beta 1 induces the transdifferentiation of human renal tubular epithelial cells: the influence of Notch1 receptor specific inhibitor. Chin J Clin Rehabilitative Tissue Engineering Res 18: 8261-8268, 2014 (In Chinese)

23. Docherty NG, Pérez-Barriocanal F, Balboa NE and López-Novoa JM: Transforming growth factor-beta1 (TGF-beta1): A potential recovery signal in the post-ischemic kidney. Ren Fail 24: 391-406, 2002.

24. Hwang M, Kim HJ, Noh HJ, Chang YC, Chae YM, Kim KH, Jeon JP, Lee TS, Oh HK, Lee YS and Park KK: TGF-beta1 siRNA suppresses the tubulointerstitial fibrosis in the kidney of ureteral obstruction. Exp Mol Pathol 81: 48-54, 2006.

25. Huang XR, Chung AC, Wang XJ, Lai KN and Lan HY: Mice overexpressing latent TGF-betal are protected against renal fibrosis in obstructive kidney disease. Am J Physiol Renal Physiol 295: F118-F127, 2008.

26. Basile DP, Martin DR and Hammerman MR: Extracellular matrix-related genes in kidney after ischemic injury: Potential role for TGF-beta in repair. Am J Physiol 275: F894-F903, 1998

27. Spurgeon KR, Donohoe DL and Basile DP: Transforming growth factor-beta in acute renal failure: Receptor expression, effects on proliferation, cellularity, and vascularization after recovery from injury. Am J Physiol Renal Physiol 288: F568-F577, 2005.

28. Gobe G, Zhang XJ, Willgoss DA, Schoch E, Hogg NA and Endre ZH: Relationship between expression of Bcl-2 genes and grow th factors in ischemic acute renal failure in the rat. J Am Soc Nephrol 11: 454-467, 2000. 
29. Kemp W, Kompa A, Phrommintikul A, Herath C, Zhiyuan J, Angus P, McLean C, Roberts S and Krum H: Urotensin II modulates hepatic fibrosis and portal hemodynamic alterations in rats. Am J Physiol Gastrointest Liver Physiol 297: G762-G767, 2009.

30. Zhang YG, Hu YC, Mao YY, Wei RH, Bao SL, Wu LB and Kuang ZJ: Transforming growth factor- $\beta 1$ involved in urotensin II-induced phenotypic differentiation of adventitial fibroblasts from rat aorta. Chin Med J (Engl) 123: 3634-3639, 2010.

31. Weiskirchen R and Meurer SK: BMP-7 counteracting TGF-beta1 activities in organ fibrosis. Front Biosci (Landmark Ed) 18 1407-1434, 2013

32. Samarakoon R, Overstreet JM, Higgins SP and Higgins PJ: $\mathrm{TGF}-\beta 1 \rightarrow \mathrm{SMAD} / \mathrm{p} 53 / \mathrm{USF} 2 \rightarrow \mathrm{PAI}-1$ transcriptional axis in ureteral obstruction-induced renal fibrosis. Cell Tissue Res 347 117-128, 2012.
33. Dai HY, He T, Li XL, Xu WL and Ge ZM: Urotensin-2 promotes collagen synthesis via ERK1/2-dependent and ERK1/2-independent TGF- $\beta 1$ in neonatal cardiac fibroblasts. Cell Biol Int 35: 93-98, 2011.

34. Onat AM, Turkbeyler IH, Pehlivan Y, Demir T, Kaplan DS, Taysi S, Ceribasi AO, Tutar E and Kisacik B: The efficiency of a urotensin II antagonist in an experimental lung fibrosis model. Inflammation 35: 1138-1143, 2012 .

35. Tzanidis A, Hannan RD, Thomas WG, Onan D, Autelitano DJ, See F, Kelly DJ, Gilbert RE and Krum H: Direct actions of urotensin II on the heart: Implications for cardiac fibrosis and hypertrophy. Circ Res 93: 246-253, 2003.

36. Zhang YG, Li YG, Liu BG, Wei RH, Wang DM, Tan XR, $\mathrm{Bu}$ DF, Pang YZ and Tang CS: Urotensin II accelerates cardiac fibrosis and hypertrophy of rats induced by isoproterenol. Acta Pharmacol Sin 28: 36-43, 2007. 